\title{
Thermal comfort index and infrared temperatures for lambs subjected to different environmental conditions
}

\author{
Tiago do Prado Paim ${ }^{1,2 *}$, Rafhael Felipe Saraiva Martins ${ }^{3}$, Cyntia Cardoso ${ }^{3}$, Bruno Dallago ${ }^{3}$, Helder Louvandini ${ }^{1}$, Concepta \\ McManus 3,4
}

\author{
'University of São Paulo/CENA - Animal Nutrition Lab., Av. \\ Centenário 303, C.P. 96 - 13.400-970 - Piracicaba, SP - \\ Brazil. \\ ²Goiano Federal Institute (IFGoiano), Campus Iporá, Av. Oeste \\ s/n - 76200-000 - Iporá, GO - Brazil. \\ 3University of Brasília/Agronomy and Veterinary College, \\ Campus Universitário Darcy Ribeiro (ICC-SUL), Asa Norte - \\ 70910-900 - Brasília, DF - Brazil. \\ ${ }^{4}$ Federal University of Rio Grande do Sul - Dept. of Animal \\ Production, Av. Bento Gonçalves, 7712 - 91540-000 - \\ Porto Alegre, RS - Brazil. \\ *Corresponding author: tiago.paim@ifgoiano.edu.br>
}

Edited by: Gerson Barreto Mourão

Received June 17, 2013

Accepted May 06, 2014

\begin{abstract}
There is an abundance of thermal indices with different input parameters and applicabilities. Infrared thermography is a promising technique for evaluating the response of animals to the environment and differentiating between genetic groups. Thus, the aim of this study was to evaluate superficial body temperatures of lambs from three genetic groups under different environmental conditions, correlating these with thermal comfort indices. Forty lambs (18 males and 22 females) from three genetic groups (Santa Inês, lle de France $\times$ Santa Inês and Dorper $\times$ Santa Inês) were exposed to three climatic conditions: open air, housed and artificial heating. Infrared thermal images were taken weekly at $6 \mathrm{~h}, 12 \mathrm{~h}$ and $21 \mathrm{~h}$ at the neck, front flank, rear flank, rump, nose, skull, trunk and eye. Four thermal comfort indices were calculated using environmental measurements including black globe temperature, air humidity and wind speed. Artificial warming, provided by infrared lamps and wind protection, conserved and increased the superficial body temperature of the lambs, thus providing lower daily thermal ranges. Artificial warming did not influence daily weight gain or mortality. Skin temperatures increased along with increases in climatic indices. Again, infrared thermography is a promising technique for evaluating thermal stress conditions and differentiating environments. However, the use of thermal imaging for understanding animal responses to environmental conditions requires further study. Keywords: Brazilian savanna, bioclimatology, thermal stress, wind protection, artificial warming
\end{abstract}

\section{Introduction}

Heat stress is considered a limiting factor to sheep rearing. Adapted animals are characterized by minimal productivity loss during a stress period (West, 2003). Many neonatal deaths are related to cold conditions, a fact often ignored in tropical climates. A healthy lamb is able to increase its metabolic rate in response to cold stress and this thermogenic reaction is related to the mobilization of brown fat (Vázquez-Vela et al., 2008). Heat production depends on body mass and heat loss depends on the superficial body area (Radostits et al., 2000).

Certain indices have been devised to describe the thermal comfort of animals. These indices have different input parameters, which distinguish their applicability. The Temperature and Humidity Index (THI) considers wet and dry bulb temperatures (Silva, 2000). Another widely used index is the Black Globe Temperature and Humidity Index (BGHI), which considers the black globe temperature, dew point temperature and thermal radiation (Buffington et al., 1981). An index developed specifically for sheep is the Thermal Comfort Index (TCI), which considers radiation, wind, air temperature, partial vapor pressure and black globe temperature as determinant variables (Barbosa and Silva, 1995). Certain indices identify either cold or heat stress conditions only, but not both conditions. Thus, Mader et al. (2010) demonstrated an adapted index to verify cold and heat stress, known as the Global Comprehension Index (GCI), which includes adjustments for relative humidity, wind speed and radiation.
Infrared thermography is a promising technique for evaluating the response of animals to the environment and differentiating between genetic groups (Paim et al., 2013). Thermography provides measurements that are highly correlated with rectal temperature and respiration rates in lambs, both important in determining heat tolerance in sheep (Castanheira et al., 2010). Paim et al. (2012) evaluated thermal comfort indices and found a positive and significant correlation between thermographic temperatures and thermal comfort indices.

In this study, we aimed to evaluate the changes in the superficial body temperature of lambs exposed to different climatic conditions, and correlate these temperatures with thermal comfort indices. We also aimed to evaluate the usefulness of infrared thermal images of animals to identify the stress status of the environment.

\section{Materials and Methods}

The study was carried out in Brasília, Federal District, Brazil $\left(15^{\circ} 47^{\prime} \mathrm{S} ; 47^{\circ} 56^{\prime} \mathrm{W} \mathrm{Gr}\right)$, during the winter (May to July of 2010). Forty lambs (18 males and 22 females) from three genetic groups: Santa Inês (SI), Ile de France $\times$ Santa Inês $(\mathrm{IF})$ and Dorper $\times$ Santa Inês $(\mathrm{DR})$ were used. The experimental period lasted eight weeks which covered the period of age increase in the lambs from 30 to 90 days before weaning and measurements were carried out weekly.

All animals were born within one week and after birth they were allocated randomly to three differ- 
ent controlled climatic conditions: Warm and Protected (WP), consisting of a $52 \mathrm{~m}^{2}$ covered pen with $13.5 \mathrm{~m}^{2}$ heated by six 250 Watt infrared lamps, $1.7 \mathrm{~m}$ above the floor (each lamp emitted total radiation equal to 8.84 Watts $\mathrm{m}^{-2}$ and this radiation did not enter into the index calculations); Protected (P), $60 \mathrm{~m}^{2}$ covered pen protected from wind with concrete walls and without artificial heating; Natural (N), $44 \mathrm{~m}^{2}$ open pen without cover, wind protection or artificial heating. Animal coat color was classified in three classes: white, black and brown. The WP, P and N environments received 14, 12 and 14 lambs respectively, with equal numbers of females and males in each group.

The lambs received water, corn silage and concentrate ad libitum, in a creep-feeding system in pens and at pasture. During the first three days of life, the lambs stayed with their dams in their pens. Thereafter, they stayed in the pens at night, from $17 \mathrm{~h}$ until $8 \mathrm{~h}$, and, during the day all animals remained in the pasture, without protection from the sun. Animals were weighed weekly in the morning before going to pasture. The milk from dams was collected weekly through hand milking using a single flask for each udder half. Somatic cell count was performed for the diagnosis of mastitis, and a reading greater than 500,000 cells $\mathrm{mL}^{-1}$ was considered as positive (Martins et al., 2013).

Infrared thermal images were taken weekly between $5 \mathrm{~h} 30$ and $6 \mathrm{~h} 30(6 \mathrm{~h}) ; 11 \mathrm{~h} 30$ and $12 \mathrm{~h} 30$ (12h); $20 \mathrm{~h} 30$ and $21 \mathrm{~h} 30(21 \mathrm{~h}$ at a distance of $2 \mathrm{~m}$ from the animal and using an emission factor equal to 0.95). QuickReport ${ }^{\circledR}$ (QBS Software Limited, United Kingdom) was used for image analysis. The line tool was used to obtain the neck temperature. The point tool was used to take front flank $(\mathrm{FF})$, rear flank $(\mathrm{RF})$, rump, nose and skull temperatures, as well as the temperature of the pen floor. The area tool was used to obtain the maximum, minimum and average temperatures on the animal trunk. The eye point was collected through a special photo taken at a distance of $1 \mathrm{~m}$ from the animal, using the point tool. Two photos per animal per collection moment (one of the animal and another special photo of the animal's eye) were taken, totaling six photos per animal per day.

Black globe temperature and relative air humidity were taken at each pen at $6 \mathrm{~h}$ and $21 \mathrm{~h}$ and on the pasture at $12 \mathrm{~h}$ using a multifunction device model. Wind speed and solar radiation at each time of measurement and maximum and minimum temperatures of the day $\left({ }^{\circ} \mathrm{C}\right)$ were taken from a meteorological station $50 \mathrm{~m}$ distant from the animals. A software program (http://www.evandro.eng.br/grapsi.html) was used to obtain wet bulb temperature, dew point temperature and partial vapor pressure. These meteorological data were used to calculate four thermal comfort indices, including Temperature and Humidity Index (THI), Black Globe temperature and Humidity Index (BGHI), Thermal Comfort Index (TCI) and Global Comprehension Index (GCI).
Kelly and Bond (1971) determined that: $T H I=A T$ - $0.55 \times(1-R H) \times A T-58)$, with AT: air temperature $\left({ }^{\circ} \mathrm{F}\right)$ and $\mathrm{RH}$ : air relative humidity $(\%)$. Buffington et al. (1981) stated that: $B G H I=B G T+(0.36 \times D P T)+41$, with BGT: black globe temperature $\left({ }^{\circ} \mathrm{C}\right)$ and DPT: dew point temperature $\left({ }^{\circ} \mathrm{C}\right)$. Barbosa and Silva (1995) estimated TCI with the equation:

$\mathrm{TCI}=(0.6678 \times A T)+(0.4969 \times P V P)+(0.5444 \times$ $B G T)+(0.1038 \times W S)$,

with $\mathrm{AT}=$ air temperature $\left({ }^{\circ} \mathrm{C}\right), \mathrm{PVP}=$ partial vapor pressure $(\mathrm{kPa}), \mathrm{BGT}=$ black globe temperature $\left({ }^{\circ} \mathrm{C}\right)$, WS $=$ wind speed $\left(\mathrm{m} \mathrm{s}^{-1}\right)$.

Mader et al. (2010) proposed the Global Comprehension Index (GCI) that is estimated with the equations below:

Equation 1 (Eq. 1) - Relative Humidity Correction Factor $\mathrm{e}^{(0.00182 \times R H+1.8 .10-5 \times A T \times R H)}\left(0.000054 \times A T^{2}+0.00192 \times\right.$ $A T-0.0246) \times(R H-30)$

Equation 2 (Eq. 2) - Wind Speed Correction Factor

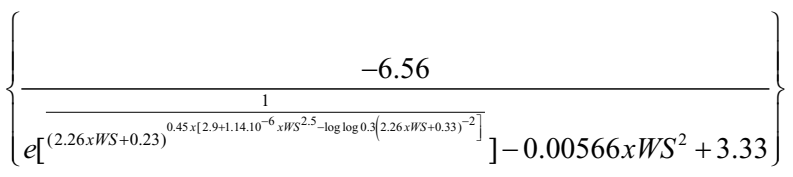

Equation 3 (Eq. 3) - Radiation Correction Factor

$0.0076 \times \mathrm{Rad}-0.00002 \times \mathrm{Rad} \times A T+0.00005 \times A T^{2}$ $\times \sqrt{\operatorname{Rad}}+0.1 \times A T-2$

Equation 3a - Direct Solar Radiation Correction Factor

$0.0057 \times \operatorname{Rad}-0.00002 \times \operatorname{Rad} \times A T+0.00005 \times A T^{2}$ $\times \sqrt{\operatorname{Rad}}$.

Equation 3b - Superficial Body Temperature Correction Factor

$0.1 \times(A T+0.019 \times \operatorname{Rad})-2$.

GCI is defined as: $A T+E q 1+E q 2+E q 3$. When there is direct solar radiation and the superficial body temperature is determined, equations $3 \mathrm{a}$ and $3 \mathrm{~b}$ can be used. The result of equation 3 is the addition of $3 a$ and 3b. The abbreviations in the previous equations stand for AT: Air temperature $\left({ }^{\circ} \mathrm{C}\right), \mathrm{RH}$ : Air Relative Humidity (\%), WS: wind speed $\left(\mathrm{m} \mathrm{s}^{-1}\right)$ and Rad: Solar radiation (Watts $\mathrm{m}^{-2}$ ).

Superficial body temperatures of animals obtained with thermal image and thermal comfort indices of each group were subjected to statistical analyses to determine the relationship between them and the mean 
comparison after analyses of variance. Superficial body temperatures and average daily weight gain were evaluated using environment, diagnosis of mastitis, and age of the lamb as fixed effects. Superficial body temperatures were also analyzed considering the thermal comfort indices as covariates. The individual animal was used as a random effect in mixed model analysis. Genetic group, environment, time of the day, sex of the lamb, coat color and age were used as fixed effects on the analysis of thermal comfort indices and superficial body temperatures.

Pearson correlation and factor analysis were carried out using all data. The factor analysis performs a variety of common factor and component analyses. All measures were used as multivariate data. The first two factors that explained the greater proportion of data variation were selected. The results of the factors, therefore, show the relationship between the variables in the study. The statistical analyses were carried out using MIXED, CORR and FACTOR procedures of the SAS (Statistical Analysis System, version 9.2). The Tukey test was used for means comparison between groups.

\section{Results}

The air temperature in the WP pens was $2^{\circ} \mathrm{C}$ and $5{ }^{\circ} \mathrm{C}(p<0.05)$ above temperatures under $\mathrm{N}$ conditions at $6 \mathrm{~h}$ and $21 \mathrm{~h}$, respectively. Group P had similar $\mathrm{RH}$ and $\mathrm{AT}$ values compared to the $\mathrm{N}$ group. $\mathrm{N}$ conditions had a wide thermal range than others. The three groups did not differ in lamb mortality and lamb deaths were lower than $10 \%$ over the experimental period. In general, the environmental indices had the highest values at $12 \mathrm{~h}$ and the lowest at $6 \mathrm{~h}$, with $21 \mathrm{~h}$ in an intermediate position (Table 1). The indices were higher in the WP group than $\mathrm{P}$ and $\mathrm{N}$ at $6 \mathrm{~h}$. At $12 \mathrm{~h}$, the indices showed no difference between groups (as all were at pasture). At $21 \mathrm{~h}, \mathrm{GCI}, \mathrm{THI}$ and BGHI had higher values in the WP group than $\mathrm{P}$, and $\mathrm{P}$ higher than $\mathrm{N}$.

The superficial body temperatures of the animals showed similar patterns between times comparing index values, $12 \mathrm{~h}$ being higher than $21 \mathrm{~h}$ and $21 \mathrm{~h}$ higher than $6 \mathrm{~h}$ (Table 2). In general, the temperature points at $6 \mathrm{~h}$ were higher in the WP group than $\mathrm{P}$ and N. Nose temperature differed between $\mathrm{P}$ and $\mathrm{N}$ groups at $6 \mathrm{~h}$, with higher values in N. Similarly, with values of $6 \mathrm{~h}$, the temperatures at $21 \mathrm{~h}$ in WP group were higher than $\mathrm{P}$ and $\mathrm{N}$ groups.

The average daily weight gain (DWG) of all animals was $216.65 \mathrm{~g}$ day $^{-1}$. Climatic condition and genetic group did not influence DWG $(p>0.05)$. Still, the mastitis status of the dam (MM) influenced DWG and correlations (Table 3) between DWG and MM were negative, medium and significant $(\mathrm{r}=-0.33 ; p=0.0001)$. In general, the correlations between indices and some superficial body temperatures were positive and high (close to 0.80). The correlations between indices and RF

Table 1 - Means of thermal comfort indices and temperatures at three times during the day in three environments.

\begin{tabular}{|c|c|c|c|c|c|c|c|c|c|}
\hline Group & & $\mathrm{m}$ and Prote & & & Protected & & & Natural & \\
\hline Time & $6 \mathrm{~h}$ & $12 \mathrm{~h}$ & $21 \mathrm{~h}$ & $6 \mathrm{~h}$ & $12 \mathrm{~h}$ & $21 \mathrm{~h}$ & $6 \mathrm{~h}$ & $12 \mathrm{~h}$ & $21 \mathrm{~h}$ \\
\hline THI & $55.53 \mathrm{cA}$ & $71.67 \mathrm{aA}$ & $67.81 \mathrm{bA}$ & $51.15 \mathrm{cB}$ & $71.56 \mathrm{aA}$ & $62.56 \mathrm{bB}$ & $49.26 \mathrm{cC}$ & $71.61 \mathrm{aA}$ & $60.41 \mathrm{bC}$ \\
\hline BGHI & $58.77 \mathrm{cA}$ & $81.80 \mathrm{aA}$ & $69.32 \mathrm{bA}$ & $53.93 \mathrm{cB}$ & $81.69 \mathrm{aA}$ & $61.79 \mathrm{bB}$ & $53.49 \mathrm{cB}$ & $81.76 \mathrm{aA}$ & $60.49 \mathrm{bC}$ \\
\hline $\mathrm{TCl}$ & $16.68 \mathrm{cA}$ & $36.79 \mathrm{aA}$ & $27.03 \mathrm{bA}$ & $12.59 \mathrm{cB}$ & $36.60 \mathrm{aA}$ & 20.92 bB & $11.89 \mathrm{cB}$ & $36.69 \mathrm{aA}$ & $19.62 \mathrm{bB}$ \\
\hline $\mathrm{GCl}$ & $16.15 \mathrm{bA}$ & $25.45 \mathrm{aA}$ & $26.25 \mathrm{aA}$ & $12.85 \mathrm{cB}$ & $25.34 \mathrm{aA}$ & $21.80 \mathrm{bB}$ & $8.62 c C$ & $25.38 \mathrm{aA}$ & $16.23 \mathrm{bc}$ \\
\hline AT $\left({ }^{\circ} \mathrm{C}\right)$ & 12.9 & 24.6 & 21 & 10.4 & 24.6 & 17.4 & 9.3 & 24.6 & 16 \\
\hline RH (\%) & 82.2 & 55 & 69.2 & 88.5 & 55 & 73.9 & 88.3 & 55 & 73.9 \\
\hline WS $\left(\mathrm{m} \mathrm{s}^{-1}\right)$ & 0 & 4.2 & 0 & 0 & 4.2 & 0 & 1 & 4.2 & 1.3 \\
\hline
\end{tabular}

Different letters in same line indicate difference $(p<0.05)$, small letters between times and capital letters between groups, using pdiff statement of SAS ${ }^{\oplus}$. THI: temperature and humidity index; BGHI: Black globe temperature and humidity index; TCl: thermal comfort index; GCl: Global Comprehension index; AT: air temperature; RH: air relative humidity; WS: wind speed.

Table 2 - Skin surface temperatures $\left({ }^{\circ} \mathrm{C}\right)$ at body points on lambs submitted to three environment conditions.

\begin{tabular}{lccccccccc}
\hline Group & \multicolumn{3}{c}{ Warm and Protected } & \multicolumn{3}{c}{ Protected } & \multicolumn{3}{c}{ Natural } \\
\hline Time & $6 \mathrm{~h}$ & $12 \mathrm{~h}$ & $21 \mathrm{~h}$ & $6 \mathrm{~h}$ & $12 \mathrm{~h}$ & $21 \mathrm{~h}$ & $6 \mathrm{~h}$ & $12 \mathrm{~h}$ & $21 \mathrm{~h}$ \\
\hline RF & $30.64 \mathrm{cA}$ & $35.00 \mathrm{aA}$ & $33.34 \mathrm{bA}$ & $29.11 \mathrm{cB}$ & $35.39 \mathrm{aA}$ & $31.91 \mathrm{bAB}$ & $29.37 \mathrm{cB}$ & $33.81 \mathrm{aA}$ & $31.38 \mathrm{bB}$ \\
Trunk & $22.91 \mathrm{cA}$ & $35.36 \mathrm{aA}$ & $26.99 \mathrm{bA}$ & $20.85 \mathrm{cB}$ & $34.98 \mathrm{aAB}$ & $24.33 \mathrm{bB}$ & $20.81 \mathrm{cB}$ & $33.61 \mathrm{aB}$ & $24.61 \mathrm{bB}$ \\
Rump & $22.01 \mathrm{cA}$ & $36.98 \mathrm{aA}$ & $26.11 \mathrm{bA}$ & $19.17 \mathrm{cB}$ & $36.56 \mathrm{aA}$ & $22.79 \mathrm{bB}$ & $18.43 \mathrm{cB}$ & $35.42 \mathrm{aA}$ & $21.18 \mathrm{bB}$ \\
FF & $30.74 \mathrm{cA}$ & $34.81 \mathrm{aA}$ & $32.93 \mathrm{bA}$ & $28.71 \mathrm{cB}$ & $35.01 \mathrm{aA}$ & $31.49 \mathrm{bB}$ & $29.72 \mathrm{cAB}$ & $33.52 \mathrm{aA}$ & $31.32 \mathrm{bB}$ \\
Neck & $23.84 \mathrm{cA}$ & $33.38 \mathrm{aA}$ & $27.23 \mathrm{bA}$ & $21.87 \mathrm{cB}$ & $32.90 \mathrm{aA}$ & $25.25 \mathrm{bB}$ & $22.56 \mathrm{cB}$ & $31.61 \mathrm{aA}$ & $24.97 \mathrm{bB}$ \\
Skull & $24.68 \mathrm{cA}$ & $35.60 \mathrm{aA}$ & $28.32 \mathrm{bA}$ & $22.99 \mathrm{cB}$ & $36.06 \mathrm{aA}$ & $25.99 \mathrm{bB}$ & $21.69 \mathrm{cC}$ & $33.60 \mathrm{aB}$ & $24.34 \mathrm{bB}$ \\
Nose & $26.94 \mathrm{cAB}$ & $34.48 \mathrm{aA}$ & $30.93 \mathrm{bA}$ & $26.27 \mathrm{cB}$ & $34.33 \mathrm{aA}$ & $28.91 \mathrm{bB}$ & $27.50 \mathrm{cA}$ & $34.37 \mathrm{aA}$ & $29.32 \mathrm{bB}$ \\
Eye & $33.83 \mathrm{cA}$ & $36.55 \mathrm{aA}$ & $35.26 \mathrm{bA}$ & $32.28 \mathrm{cB}$ & $36.59 \mathrm{aA}$ & $34.38 \mathrm{bB}$ & $32.56 \mathrm{cB}$ & $36.77 \mathrm{aA}$ & $34.56 \mathrm{bAB}$ \\
Floor & $18.65 \mathrm{cA}$ & $33.16 \mathrm{aA}$ & $23.51 \mathrm{bA}$ & $16.36 \mathrm{cB}$ & $31.92 \mathrm{aA}$ & $21.46 \mathrm{bB}$ & $14.25 \mathrm{cC}$ & $32.09 \mathrm{aA}$ & $19.09 \mathrm{bC}$ \\
\hline
\end{tabular}

Different letters at same line indicate difference $(p<0.05)$, small letters between times and capital letters between environments, using pdiff statement. RF: rear flank; FF: front flank. Floor: temperature at pen floor. 
Table 3 - Correlations between lamb weights, skin gsurface temperature points on lambs and thermal comfort indices.

\begin{tabular}{|c|c|c|c|c|c|c|c|c|c|c|c|c|c|c|c|c|}
\hline & Age & Weight & DWG & Mastitis & RF & Trunk & Rump & $\mathrm{FF}$ & Neck & Skull & Nose & Floor & Eye & $\mathrm{THI}$ & BGHI & $\mathrm{TCl}$ \\
\hline Weight & $0.75^{\star \star \star *}$ & & & & & & & & & & & & & & & \\
\hline DWG & $0.09^{*}$ & $0.49^{* * *}$ & & & & & & & & & & & & & & \\
\hline Mastitis & $-0.04^{\text {ns }}$ & $-0.21^{* *}$ & ${ }^{*}-0.33^{* * *}$ & & & & & & & & & & & & & \\
\hline $\mathrm{RF}$ & $0.19^{* * *}$ & $0.16^{* * *}$ & $0.01^{\text {ns }}$ & $-0.04^{\text {ns }}$ & & & & & & & & & & & & \\
\hline Trunk & $0.11^{* *}$ & $0.08^{\mathrm{ns}}$ & $0.07^{\text {ns }}$ & $-0.01^{\text {ns }}$ & $0.62^{\circ}$ & & & & & & & & & & & \\
\hline Rump & $0.02^{\mathrm{ns}}$ & $-0.02^{\text {ns }}$ & $0.02^{\text {ns }}$ & $-0.01^{\text {ns }}$ & $0.58^{\circ}$ & * 0.93 * * & & & & & & & & & & \\
\hline $\mathrm{FF}$ & $0.21^{* * *}$ & $0.19^{* * *}$ & $0.02^{\text {ns }}$ & $-0.01^{\text {ns }}$ & $0.89^{\circ}$ & ${ }^{*} 0.62^{* *}$ & * $0.58^{* *}$ & & & & & & & & & \\
\hline Neck & $0.11^{*}$ & $0.08^{\text {ns }}$ & $0.06^{\text {ns }}$ & $-0.00^{\text {ns }}$ & $0.64^{\prime}$ & * 0.91 * * & * $0.88^{* *}$ & * 0.6 & & & & & & & & \\
\hline Skull & $0.68^{\text {ns }}$ & $0.03^{\text {ns }}$ & $0.04^{\text {ns }}$ & $0.03^{\text {ns }}$ & $0.60^{\circ}$ & * 0.91 ** & * 0.91 * * & * 0.6 & * $0.89 *$ & & & & & & & \\
\hline Nose & $0.11^{*}$ & $0.12^{*}$ & $0.08^{\text {ns }}$ & $0.01^{\mathrm{ns}}$ & $0.52^{\circ}$ & * $0.75^{* *}$ & * 0.71 * * & * 0.5 & ${ }^{*} 0.76$ * & * 0.73 * & & & & & & \\
\hline Floor & $0.13^{* *}$ & $0.10^{*}$ & $0.05^{\mathrm{ns}}$ & $-0.04^{\text {ns }}$ & $0.56^{\circ}$ & * $0.87^{* *}$ & * $0.86^{\text {* * }}$ & * 0.5 & * $0.83^{*}$ & * 0.86 * & * 0.73 * & & & & & \\
\hline Eye & $0.26^{* * *}$ & $0.03^{* * *}$ & $0.12^{* *}$ & $-0.11^{\text {ns }}$ & 0.61 & * $0.70^{* *}$ & ${ }^{*} 0.64^{* *}$ & * 0.6 & * 0.71 * & ${ }^{*} 0.68$ * & * 0.68 * & * 0.71 * & & & & \\
\hline THI & $0.05^{\mathrm{ns}}$ & $0.03^{\text {ns }}$ & $0.01^{\text {ns }}$ & $0.00^{\text {ns }}$ & $0.60^{\circ}$ & * 0.81 ** & $0.72^{* *}$ & * 0.6 & * 0.81 * & * $0.79 *$ & * 0.72 * & * 0.89 * & ${ }^{*} 0.71$ & & & \\
\hline $\mathrm{BGH}$ & $0.09^{*}$ & $0.06^{\text {ns }}$ & $0.02^{\mathrm{ns}}$ & $-0.01^{\text {ns }}$ & $0.59^{\prime}$ & * 0.84 * * & $0.85^{* *}$ & * 0.5 & ${ }^{*} 0.83 *$ & * 0.84 * & * $0.72 *$ & ${ }^{*} 0.93$ * & ${ }^{*} 0.68$ & ${ }^{*} 0.96$ & & \\
\hline $\mathrm{TCl}$ & $0.10^{*}$ & $0.07^{\mathrm{ns}}$ & $0.02^{\mathrm{ns}}$ & $-0.01^{\text {ns }}$ & $0.60^{\circ}$ & * $0.84^{* *}$ & $0.84^{* *}$ & * 0.6 & * $0.83 *$ & ${ }^{*} 0.83^{*}$ & * $0.73 *$ & * 0.93 * & ${ }^{*} 0.70$ & * 0.97 & * 1.00 * & \\
\hline $\mathrm{GCl}$ & $0.03^{\text {ns }}$ & $-0.01^{\text {ns }}$ & $-0.02^{\text {ns }}$ & $0.02^{\mathrm{ns}}$ & $0.59^{\circ}$ & ${ }^{*} 0.74$ ** & $0.74^{* *}$ & * 0.5 & * 0.74 * & * $0.75^{*}$ & ${ }^{*} 0.65$ * & * 0.84 * & ${ }^{*} 0.66$ & * 0.97 & * 0.90 * & ${ }^{*} 0.92^{* * *}$ \\
\hline
\end{tabular}

${ }^{*} p<0.05,{ }^{* *} p<0.01,{ }^{* * *} p<0.001$, ns - not significant. DWG: daily weight gain; Mastitis: diagnosis of mastitis in dams; RF: rear flank temperature point; FF: front flank temperature point; THI: temperature and humidity index; BGHI: Black globe temperature and humidity index; TCl: thermal comfort index; GCl: Global Comprehension index.

were close to 0.60 (Table 3). Moreover, the correlations between age, weight, DWG, MM, temperatures and indices were low and not significant.

In cold situations (at $21 \mathrm{~h}$ ), lambs tended to lie down and protect $\mathrm{FF}, \mathrm{RF}$ and neck points. Hence, the $\mathrm{P}$ and $\mathrm{N}$ groups had similar values for these temperature points. Less interaction (physical contact) between lambs and dams was observed when artificial warming by infrared lamps and wind protection was used, demonstrating a change in lamb behavior attributable to environmental conditions.

The IF animals had lower ( $p=0.045)$ skull temperatures (next to $1^{\circ} \mathrm{C}$ ) than DR. Lamb gender had no effect on temperature $(p>0.05)$. Coat color influenced the trunk, rump and neck temperatures $(p=0.027$; $0.001 ; 0.039$; respectively), since white coated animals had lower temperatures than brown.

Higher superficial body temperatures were in line with higher thermal comfort indices (Figure 1). Mastitis in dams did not affect the temperature of the offspring. The second factor showed higher weights, ages and DWG related to negative mastitis status in the dam. The variance captured by the two factors was $72.80 \%$ of data variability.

\section{Discussion}

The temperatures at $12 \mathrm{~h}$ were between 32 and 40 ${ }^{\circ} \mathrm{C}$, defined as a heat stress situation for lambs, according to Cezar et al. (2004). These authors state that temperatures higher than $31{ }^{\circ} \mathrm{C}$ lead to increases in rectal temperature and heartbeat rate in the Santa Inês sheep. According to Vincent et al. (2005), the thermal range in the tropics throughout the year is low (lower than $5^{\circ} \mathrm{C}$ ), while the daily thermal range is high (close to $10^{\circ} \mathrm{C}$ ).

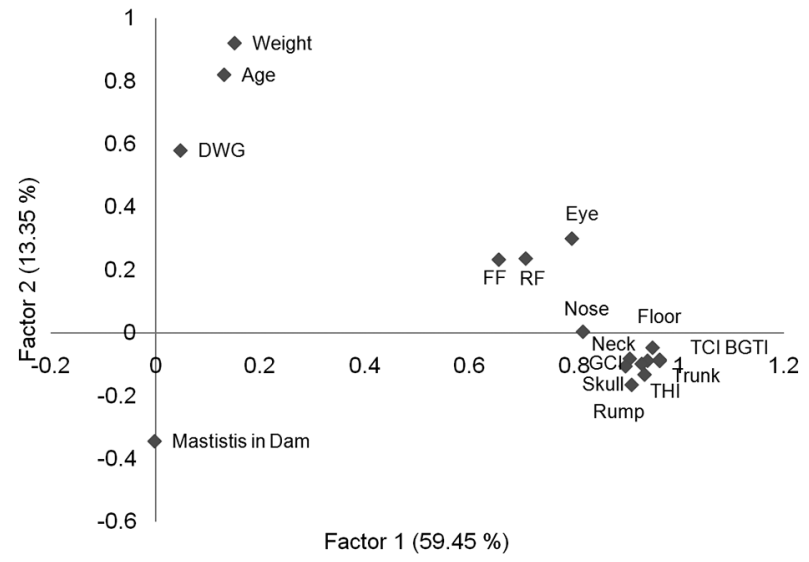

Figure 1 - Two first factors of lamb weight and age, thermal comfort indices and skin surface temperatures. The first two factors explained $72.8 \%$ of the variance between variables.

The measurements in this study showed wide thermal ranges, higher than $10{ }^{\circ} \mathrm{C}$, especially in the $\mathrm{N}$ group which had the widest thermal range. The warming in the WP group led to a lower thermal range, which can improve lamb growth and feed efficiency as a result of the lower energy expenditure required to maintain body temperature (Ames and Brink, 1977).

Nose temperature had a different pattern in relation to other temperature points. This result agrees with that found by Paim et al. (2013) in a similar study, which also found a different nasal temperature behavior compared to other superficial body temperature points. Probably, this point has a closer relationship to the internal temperature, as the animals use respiration to exchange heat with the environment (Kimmel at al., 1992). 
Wind action did not influence the results, probably because the animals displayed thermal conservation behavior. These results showed that wind protection alone is not effective in increasing the superficial body temperatures of lambs in cold situations, because the animal modifies its behavior aiming to conserve or produce more heat (Young, 1981). Those animals exposed to a more challenging environment (such as the $\mathrm{N}$ and $\mathrm{P}$ group) may eat more, aiming to increase their metabolism and produce more heat (Ames and Brink, 1977), which consequently can lead to lower feed efficiency, which was not measured here.

THI, BGHI, and TCI differed between the three evaluation periods, showing the highest heat stress at $12 \mathrm{~h}$ which was expected, as all animals were in the pasture at this time. The WP group showed higher index values at $6 \mathrm{~h}$ and $21 \mathrm{~h}$, indicating that artificial heating promoted lower daily thermal range.

In general, the four indices calculated agree with each other in relation to climatic characterization at each time and group. TCI is better at determining thermal discomfort situations and can be considered a more accurate index than THI and BGHI, because TCI is more highly correlated with rectal temperature and respiration than the others (Neves et al., 2009). However, in this study, the THI and GCI were able to differ between groups at $6 \mathrm{~h}$ while the other indices differentiated WP only from the other groups, which can indicate that THI and GCI were more useful than others.

THI values at $6 \mathrm{~h}, 12 \mathrm{~h}$ and $21 \mathrm{~h}$ in this study did not demonstrate thermal stress (Marai et al., 2007). Nevertheless, BGHI indicated that these animals suffered high thermal stress at $12 \mathrm{~h}$ (Paim et al., 2012). The TCI values found at $12 \mathrm{~h}$ showed that animals suffered heat stress, which was confirmed by Neves et al. (2009) in semiarid conditions. The GCI revealed that animals suffered a thermal heat discomfort situation at $12 \mathrm{~h}$ (Mader et al., 2010).

The N group had the lowest GCI value at $6 \mathrm{~h}$ (8.62), but this is not considered a cold stress situation (Mader et al., 2010). According to these authors, values below five are indicative of cold discomfort in susceptible animals, such as lambs. In the full experimental period, values below five were found in only one day in the $\mathrm{N}$ group (3.62). This may explain why the climatic condition groups did not differentiate between DWG and lamb mortality, since the artificial warming aimed to protect them against possible cold conditions and these cold stress situations happened infrequently. Hence, cold stress in mid-west conditions in Brazil (Brazilian savanna), in dry periods, can occur but is not a predominant condition.

The values of temperature points found in this study agree with other similar studies (Neves et al., 2009; Paim et al., 2013). However, Paim et al. (2013) observed differences due to different genetic groups, not found in this study. This may be related to the number of animals used in each study, since those authors used more than 120 lambs whereas we used only 40 lambs.
Moreover, Paim et al. (2013) used Bergamasca as one of the genetic groups and here we used Dorper $\times$ Santa Inês which could also contribute to not having found differences between genetic groups.

Coat color influenced the temperatures at trunk, rump and neck. Brown-coated animals had higher values than white. McManus et al. (2009) evaluated adult sheep and reported that animals with black coats had higher rectal temperatures compared to animals with white and brown coats. Therefore, the results agree that animals with white coats tend to show lower superficial body temperatures, as these reflect more light than others.

The first factor showed that superficial body temperatures and thermal comfort indices increased together. High correlations were also seen between them. Superficial body temperatures tended to increase as thermal comfort indices rose. This implies that the infrared method is a promising technique for the evaluation of the thermal stress conditions of each animal in each specific environment, and has the advantages of being both non-invasive and quick.

According to the second factor, lambs with lower DWG showed higher rates of positive mastitis in the dam, which agrees with Keisler et al. (1992), showing that mastitis status in dams impacts lamb growth. Moreover, the high economic loss associated with mastitis in flocks is well characterized in the literature (Mavrogianni et al., 2011).

\section{Conclusions}

Artificial warming by infrared lamps and wind protection caused a lower daily thermal range for lambs. Cold stress situations happened infrequently during the experimental period and, consequently, the controlled conditions did not influence the daily weight gain of lambs nor lamb mortality. Superficial body temperatures tended to increase as indices rose, which reinforces the usefulness of the infrared method as a technique for the evaluation of thermal stress conditions.

\section{Acknowledgements}

To FAPDF, CNPq and INCT-Pecuária (CNPq/FAPEMIG/MCT) for financing and scholarships. To IF Goiano for supporting the research.

\section{References}

Ames, D.R.; Brink, D.R. 1977. Effect of temperature on lamb performance and protein efficiency ratio. Journal of Animal Science 44: 136-144.

Barbosa, O.R.; Silva, R.G. 1995. Thermal comfort indices for sheep. Boletim de Indústria Animal 52: 29-35 (in Portuguese, with abstract in English).

Buffington, D.E.; Collazoarocho, A.; Canton, G.H. 1981. Black globe- humidity index (BGHI) as comfort equation for dairy cows. Transactions of the ASAE 24: 711-714. 
Castanheira, M.; Paiva, S.R.; Louvandini, H.; Landim, A.; Fiorvanti, M.C.S.; Dallago, B.S.; Correa, P.S.; McManus, C. 2010. Use of heat tolerance traits in discriminating between groups of sheep in central Brazil. Tropical Animal Health and Production 42: 1821-1828.

Cezar, M.F.; Souza, B.B.; Souza, W.H. 2004. Evaluation of physiological parameters of sheep from Dorper, Santa Inês and their crosses in climatic conditions of northeast semi-arid. Ciência e Agrotecnologia 28: 614-620 (in Portuguese, with abstract in English).

Keisler, D.H.; Andrews, M.; Moffat, R.J. 1992. Subclinical mastitis in ewes and its effect on lamb performance. Journal of Animal Science 70: 1667-1681.

Kelly, C.F.; Bond, T.E. 1971. Bioclimatic factors and their measurements. p. 71-92. In: National Academy of Sciences: a guide to environmental research on animals. NAS, Washington, DC, USA.

Kimmel, E.; Arkin, H.; Berman, A. 1992. Evaporative cooling of cattle: transport phenomena and thermovision. American Society of Agricultural and Biological Engineers 92: 28-40.

Mader, T.L.; Johnson, L.J.; Gaughan, J.B. 2010. Components of the comprehensive climate index. Journal of Animal Science. Available at: http://jas.fass.org/content/early/2010/01 /29/ jas.2009-2586 [Accessed Mar 20, 2011]

Marai, I.F.M.; El-Darawany, A.A.; Fadiel, A.; Abdel-Hafez, M.A.M. 2007. Physiological traits as affected by heat stress in sheep: a review. Small Ruminant Research 71: 1-12.

Martins, R.F.S.; Paim, T.P.; Cardoso, C.A.; Dallago, B.S.L.; Melo, C.B.; Louvandini, H.; McManus, C. 2013. Mastitis detection in sheep by infrared thermography. Research in Veterinary Science 94: 722-724.

Mavrogianni, V.S.; Menzies, P.I.; Fragkou, I.A.; Fthenakis, G.C. 2011. Principles of mastitis treatment in sheep and goats. Veterinary Clinics of North America: Food Animal Practice 27: 115-120.

McManus, C.; Paludo, G.R.; Louvandini, H. 2009. Heat tolerance in naturalized brazilian sheep: physiological and blood parameters. Tropical Animal Health and Production 41: 95-101.
Neves, M.L.M.W.; Azevedo, M.; Costa, L.A.B. 2009. Critical levels of the thermal comfort index for Santa Inês sheep under grazing at the agreste region of Pernambuco state. Acta Scientiarum. Animal Sciences 31: 169-175 (in Portuguese, with abstract in English).

Paim, T.P.; Borges, B.O.; Lima, P.M.T. 2012. Relation between thermographic temperatures of lambs and thermal comfort indices. International Journal of Applied Animal Sciences 1: 108-115.

Paim, T.P.; Borges, B.O.; Lima, P.M.T. 2013. Thermographic evaluation of climatic conditions on lambs from different genetic groups. International Journal of Biometeorology 57: 59-66.

Radostits, O.M.; Gay, C.C.; Blood, D.C.; Hinchcliff, K.W. 2000. Veterinary Medicine: A Textbook of Cattle, Sheep, Pigs, Goats and Horses. 9ed. W.B. Saunders, London, UK.

Silva, R.G. 2000. Introduction to Animal Bioclimatology. Nobel, São Paulo, Brazil (in Portuguese, with abstract in English).

Vázquez-Vela, M.E.F.; Torres, N.; Tovar, A.R. 2008. White adipose tissue as endocrine organ and its role in obesity. Archives of Medical Research 39: 715-728.

Vincent, L.A.; Peterson, T.C.; Barros, V.R.; Marino, M.B.; Rusticucci, M.; Carrasco, G.; Ramirez, E.; Alves, L.M.; Ambrizzi, T.; Berlato, M.A.; Grimm, A.M.; Marengo, J.A.; Molion, L.; Moncunill, D.F.; Rebello, E.; Anunciação, Y.M.T.; Quintana, J.; Santos, J.L.; Baez, J.; Coronel, G.; Garcia, J.; Trebejo, I.; Bidegain, M.; Haylock, M.R.; Karoly, D. 2005. Observed trends in indices of daily temperature extremes in South America 1960-2000. Journal of Climate 18: 5011-5023.

West, J.W. 2003. Effects of heat stress on production in dairy cattle. Journal of Dairy Science 86: 2131-2144.

Young, B.A. 1981. Cold stress as it affects animal production. Journal of Animal Science 52: 154-163. 